\title{
ANALISIS DAMPAK POTENSIAL PENGGUNAAN BUKU AJAR PENDIDIKAN DEMOKRASI BERBASIS NILAI DALAM MENGEMBANGKAN SIKAP DEMOKRATIS MAHASISWA
}

\author{
Puspa Dianti ${ }^{1}$, Sri Artati Waluyati ${ }^{2}$, Husnul Fatihah ${ }^{3}$ \\ ${ }^{1,2,3}$ FKIP Universitas Sriwijaya, Indonesia \\ 'Email; puspadianti@fkip.unsri.ac.id
}

\begin{abstract}
ABSTRAK
Tujuan Penelitian ini adalah untuk mengetahui dampak potensial penggunaan buku ajar berbasis nilai pada Mata Kuliah Pendidikan Demokrasi dalam mengembangkan sikap demokratis mahasiswa. Buku ajar yang digunakan dalam penelitian ini telah dikembangkan dengan berbasis nilai yang diharapkan dapat mengembangkan sikap demokratis mahasiswa. Dampak potensial penggunaan buku ajar ini dilihat dari peningkatan nilai mahasiswa ketika menggunakan buku ajar Pendidikan Demokrasi berbasis nilai dan respon yang ditunjukkan oleh mahasiswa selama proses pembelajaran berlangsung. Untuk mencapai tujuan penelitian tersebut, peneliti menggunakan metode pengumpulan data berupa tes dan observasi. Berdasarkan data hasil tes terlihat peningkatan nilai hasil belajar siswa setelah menggunakan buku ajar Pendidikan Demokrasi berbasis nilai dengan nilai rata-rata tes awal 5,3 dan rata-rata nilai tes akhir 7,2 yang menunjukkan selisih 1,9. Selanjutnya, persentase pengamatan respon siswa selama proses pembelajaran berlangsung yang mengacu pada nilai demokratis yang ditunjukkan mahasiswa mencapai $73,3 \%$ dengan kriteria baik. Hal tersebut menunjukkan bahwa buku ajar Pendidikan Demokrasi berbasis nilai memiliki dampak potensial dalam mengembangkan sikap demokratis mahasiswa.
\end{abstract}

Kata Kunci : Dampak Potensial; Buku Ajar; Sikap Demokratis.

\section{ABSTRACT}

This study aimed at finding out the potential effect of value-based textbook on Democratic Education course in promoting the students' democratic attitude. In hope to be able to develop the students' democratic attitude, the developed textbook used in this study was a value-based one. The potential effect of this textbook was indicated by the increase of students' score and by the response given by the students during the learning process of Democratic Education course. To achieve the objectives of the study, the data were collected through test and observation. Based on the results, there was an increase on students' score after using Democratic Education value-based textbook with the average of 5,3 for the pretest and 7,2 for the post-test, respectively; there was 1,9 score gap between the pre- and posttest. During the learning process referring to the democratic value, moreover, it was observed that $73,3 \%$ of the students responded positively. These showed that Democratic Education value-based textbook had a potential effect in promoting the students' democratic attitude.

Keywords: Potential Effect; Textbook; Democratic Attitude.

\section{PENDAHULUAN}

Sikap demokratis merupakan salah satu sikap yang harus dimiliki oleh setiap warga negara. Dengan memiliki sikap yang demokratis akan membantu terciptanya suasana kehidupan yang harmonis antar warga negara maupun antar warga negara dengan pemerintah. Secara kodrat, manusia merupakan makhluk sosial yang dalam hidupnya akan selalu melakukan interaksi terhadap sesamanya. Seperti dikemukakan Widjaja (1986) "manusia dapat dikatakan tidak terlepas dari lingkungan masyarakat tempat hidup bersama serta berinteraksi dengan individu yang lain". Sebelum membahas mengenai demokrasi, terlebih dahulu dapat dipahami tentang pengertian sikap. 
Hal senada juga diungkapkan oleh Winkel (2007) bahwa merupakan kemampuan internal yang berperan sekali dalam mengambil tindakan, lebih-lebih bila terbuka kemungkinan untuk bertindak." Pengertian tersebut menunjukkan bahwa sikap yang diambil dalam suatu kondisi tertentu akan berpengaruh terhadap kehidupannya. Oleh karena itu, diperlukan kemampuan untuk bertindak secara tepat (bersikap) agar kita membuat atau mengambil keputusan terhadap hal-hal yang ada di lingkungan sekitar kita. Salah satu sikap yang ditunjukkan oleh seseorang yang secara kodrat merupakan makhluk sosial. Sikap demokratis tentunya tidak dapat muncul dengan sendirinya melainkan harus ditempah melalui suatu pendidikan dan pembiasaan. Sebagaimana hal tersebut sesuai dengan yang diamanahkan dalam tujuan pendidikan nasional Indonesia yang terdapat pada UU Sistem Pendidikan Nasional Indonesia No 20 Tahun 2003 Pasal 3 yang berbunyi:

Pendidikan nasional berfungsi
mengembangkan kemampuan
dan membentuk watak serta
peradaban bangsa yang
bermartabat dalam rangka
mencerdaskan kehidupan bangsa,
bertujuan untuk berkembangnya
potensi peserta didik agar
menjadi manusia yang beriman
dan bertakwakepada Tuhan Yang
MahaEsa, berakhlakmulia, sehat,
berilmu, cakap, kreatif, mandiri,
dan menjadi warga negara yang
demokratis serta bertanggung
jawab.

Dalam kutipan UU Sisdiknas tersebut jelas tersurat bahwa yang menjadi salah satu tujuan pendidikan Indonesia adalah menjadikan warga negara yang demokratis. Selain itu pada tahun 2010, Kemendiknas juga telah membuat grand design pendidikan karakter yang di dalamnya telah ditentukan nilai-nilai yang harus ditanamkan pada peserta didik dalam proses pembelajaran. sebagai upaya membangun karakter bangsa. Dalam Kemendiknas (2010) diuraikan bahwa nilai-nilai yang harus ditanamkan dalam diri peserta didik, yaitu nilai religius, jujur, toleransi, disiplin, kerja keras, kreatif, mandiri, demokratis, rasa ingin tahu, nasionalisme, cinta tanah air, menghargai prestasi, komunikatif, cinta damai, gemar membaca, peduli lingkungan, peduli sosial, tanggung jawab.

Dari ke 18 karakter yang dirumuskan oleh Kemendiknas tersebut pada bagian kedelapan disebutkan bahwa karakter demokratis yakni sikap dan cara berpikir yang mencerminkan persamaan hak dan kewajiban secara adil dan merata antara dirinya dengan orang lain. Penekanan nilai demokratis pada tujuan pendidikan Indonesia dan grand design pendidikan karakter menunjukkan bahwa pentingnya penanaman nilai demokratis tersebut kepeda peserta didik. Untuk menjadikan seseorang memiliki menuju nilai demokratis (demokratisasi) tentunya tidak dapat dilakukan secara cepat dan muda melainkan harus ada proses yang dilalui dalam menanamkan nilai tersebut.

Pembentukan sikap demokratis pada warga negara Indonesia tentunya harus mengacu pada jenis demokrasi yang berlaku di Indonesia, yaitu demokrasi Pancasila. Watak atau sikap kewarganegaraan adalah sikap dan kebiasaan berpikir warganegara yang menopang berkembangnya fungsi sosial yang sehat dan jaminan kepentingan umum dari sistem demokrasi (Muhibbin \& Sumardjoko). Hal ini sebagaimana dikemukakanolehSinal(2017)menjelaskan "demokrasi Indonesia adalah kerakyatan yang dipimpin oleh hikmat kebijaksanaan dalam permusyawaratan perwakilan, yang berdasarkan Ketuhanan yang Maha Esa, Kemanusiaan yang Adil dan beradab, 
persatuan Indonesia, dan bertujuan untuk mewujudkan keadilan sosial bagi seluruh rakyat Indonesia (demokrasi Pancasila)" - Penjelasan mengenai ciri khas yang dikemukakan oleh Sinal jelas tersurat mengenai demokrasi Pancasila yang saat ini berlaku di Indonesia, yang ciri khas adalah musyawarah pemusyawaratan perwakilan yang mengacu pada nilai-nilai Pancasila yang merupakan ideologi Negara Indonesia.

Selanjutnya, penjelasan mengenai demokrasi Pancasila, juga dikemukakan oleh Ranjabar (2019) bahwa paham demokrasi yang Indonesia yang mengacu pada Pancasila, memiliki unsur utama berupa adanya unsur musyawarah yang jelas disebutkan dalam sila keempat. Selanjutnya, kerakyatan berarti bahwa pemerintah bersama rakyat melalui perwakilan, mengambil keputusan tentang kebijaksanaan bernegara, sedangkan inti dari musyawarah adalah win-win solution. Kedua pedapat yang dikemukaan mengenai demokrasi Pancasila tersebut memiliki makna yang sejalan bahwa demokrasi Indonesia adalah demokrasi yang cirinya adalah musyawarahyang ditandai dengan mengacu pada Pancasila. Berikut merupakan parameter tercapainya kehidupan demokratis dalam masyarakat, yaitu "penghargaan terhadap hak-hak individu, mengindahkan tata krama, semangat kerjasama, adanya rotasi kekuasaan, kesetaraan, toleransi, transparansi, dan partisipasi masyarakat." (Gaffar dalam Suacana: 2015).

Secara umum Fadhilah \& Nuraina (2011) mengungkapkan bahwa terbentuknya demokrasi dan perkembangannya di Indonesia harus diperkuat dengan faktor internal dari bangsa Indonesia sendiri yaitu demokrasi yang bersumber dari nilai budaya dan ideologi politik Indonesia. Nilai budaya dan ideologi politik Indonesia tidak lain adalah demokrasi Pancasila.

Salah satu cara atau sarana untuk meningkatkan kualitas sumber daya manusia untuk mendukung demokrasi yang sesuai dengan nilai budaya bangsa Indonesia yaitu melalui pendidikan. Keseluruhan proses pendidikan di sekolah, kegiatan belajar merupakan kegiatan yang paling utama. Keberhasilan proses pembelajaran ditentukan oleh ketiga aspek utama, yaitu peserta didik, pendidik, dan sumber belajar (Mufidah, 2016).

Terkait dengan ketiga hal yang diungkapkan oleh Mufidah di atas, Rodiyana (2019) mengemukakan bahwa dalam pendidikan demokrasi, Pendidikan Kewarganegaraan adalah salah satu mata pelajaran yang memiliki peran yang sangat penting. Hal ini mengingat Pendidikan Kewarganegaraan memiliki peran untuk menjadikan dan menghasilkan manusiamanusia yang memiliki pengetahuan dan pemahaman tentang nilai demokrasi.

Melalui pembelajaran PPKn Peserta didik diharapkan mampu mengembangkan sikap demokratis (Ulfah dkk, 2018). Hal senada diperkuat oleh Cholisin (2005) Pendidikan Pancasila dan Kewarganegaraan menjadi salah satu mata pelajaran wajib yang harus ditempuh oleh peserta didik baik di jenjang Sekolah Dasar (SD), Sekolah Menengah Pertama (SMP), maupun Sekolah Menengah Atas, Sekolah Menengah Kejuruan, dan Madrasah Aliyah (SMA/ SMK/MA). Pendidikan Pancasila dan Kewarganegaraan (PPKn) memiliki tiga kompetensi yang terdiri dari pengetahuan, ketrampilan dan sikap (civic knowledge, civic skill, and civic disposition). Diantara kompetensi tersebut terdapat dua kompetensi yang menjadi faktor penting untuk menyiapkan peserta didik menjadi warga negara yang baik (good citizen) yaitu civic knowledge (berpikir kritis) dan civic disposition (sikap demokratis). Warga negara baik merupakan warga negara yang sadar melaksanakan hak dan kewajibannya secara seimbang. Kesadaran terhadap hak dan kewajiban yang dimiliki setiap warga negara mampu menjadikan seorang warga 
negara yang berfikir kritis, partisipatif, dan bertanggung jawab.

Terdapat beberapa penelitian mengenai pendidikan demokrasi. Penelitian yang dilakukan oleh Gunarsi dkk (2014) menguraikan bahwa bentuk nilai demokrasi yang ditunjukkan oleh mahasiswa dalam proses pembelajaran dapat berupa malakukan interaksi dengan mahasiswa lain dalam bentuk diskusi, memberikan saran atau pendapat kepada mahasiswa lainnya, berlapang dada dalam menerima saran kritik dari mahasiswa lain, membuat suatu keputusan melalui musyawarah, dan menyelesaikan tugas yang diberikan secara bersama dalam kelompoknya. Selanjutnya, menurut Winarno (dalam Aulawi dan Srinawati: 2019) menguraikan bahwa pendidikan demokrasi sebenarnya telah dilakukan melalui pelajaran Pendidikan Kewarganegaraan, ataupun mata pelajaran sebelumnya seperti, PPKn, PMP, ataupun civics yang nilai demokrasinya terlihat dari perilaku demokrasi yang ditunjukkan peserta didik di dalam kelas, luar atau lingkungan sekolah. Sikap demokratis yang ditunjukkan oleh peserta didik terlihat dari keberanian para peserta didik dalam mengemukakan pendapat, sikap menghargai pendapat sesama temannya, dan mendengarkan pendapat yang dikemukakan oleh temannya. Pendapat juga senada seperti yang disebutkan oleh (Wahab dan Sapriya, 2011) bahwa kelas civic harusnya menjadi laboratorium demokrasi, yang mempelajari pertumbuhan dan mempraktikkan dasar-dasarnya. Hal tersebut menunjukkan bahwa pendidikan demokrasi sesungguhnya juga telah terintegrasi dalam pembelajaran PPKn dan pembelajaran demokrasi tidak hanya mengacu pada materi mengenai demokrasinya saja tetapi juga semua yang terjadi di dalam kelas.

Hasil penelitian lain yang dilakukan oleh Nurdyansyah \& Lestari (2018) dari pengembangan buku ajar memenuhi kriteria valid dengan hasil validasi ahli desain mencapai $30 \%$, hasil validasi ahli konten mencapai $60 \%$, hasil validasi ahli bahasa mencapai 40\%, hasil uji coba perseorangan mencapai $100 \%$, uji coba kelompok kecil mencapai 94\%, dan hasil uji coba kelompok besar mencapai $72 \%$. Hasil analisis uji t menggunakan SPSS 15 yang menunjukkan nilai $p$-value statistik uji $\mathrm{t}$ adalah sebesar 0.00 yang berarti $(<0.05)$, maka dapat disimpulkan bahwa Ho ditolak Ha diterima. Hal tersebut berarti terdapat pengaruh yang signifikan pada rata-rata nilai pretest dan postest. Dan hasil penilaian karakter religius dan tanggungjawab mengalami perubahan yang sangat meningkat setelah menggunakan buku ajar trampil Basa Jawi piwulang 5 pengalamanku berbasis karakter islam kelas I di MI Nurur Rohmah Jasem Sidoarjo.

Selanjutnya, Zuriah (2008) juga mengemukakan bahwa dalam memberikan pendidikan demokratis, peserta didik diarahkan untuk dapat menunjukkan sikap saling menghargai berbagai perbedaan yang ada di atara satu sama lainnya. Dalam pendidikan tersebut peserta juga diarahkan untuk dapat menjadi orang yang terbuka dan berani mengakui dan menerima ketika pendapatnya belum bias digunakan atau secara peserta didik dalam forum demokrasi tidak dapat memaksakan pendapatnya. Hal ini juga senada dengan hasil penelitian yang dilakukan oleh Chayati, dkk (2015) mengemukakan bahwa dalam memberikan pembelajaran nilai-nilai demokrasi di kelas yang harus menjadi fokus perhatiannya adalah bagaimana cara menghormati orang lain dengan kondisi perbedaan yang ada, menjauhi kekerasan dan melaksanakan dengan penuh tanggung jawab terhadap tugas yang diberikan. Ketiga pendapat di atas sudah cukup memberikan pemahaman mengenai bentuk sikap demokratis yang dapat ditunjukkan oleh peserta didik dalam pembelajaran di kelas.

Penanaman sikap demokratis yang telah diuraikan sebelumnya tentu tidak 
dapat dicapai dengamn mudah dan cepat melainkan harus melalui suatu proses. Salah satu cara yang dapat dilakukan adalah melalui pendidikan demokrasi. Bidang pendidikan dianggap paling strategis dalam pencapaian demokratisasi tersebut. Sebagaimana dikemukakan oleh Azra (dalam Suharto: 2005), bahwa "cara yang paling stratgis untuk "mengalami demokrasi" (experience-ingdemocracy) adalah melalui apa yang disebut sebagai democracy education yang dapat dipahami sebagai sosialisasi, diseminasi, dan aktualisasi konsep, sistem, nilai, budaya, dan praktik demokrasi melalui pendidikan."

Selanjutnya, pendidikan demokrasi yang telah ada tentu mengacu pada visi dan misi yang telah ada. Visi pendidikan demokrasi adalah sebagai wahana substantive pedagosis, dan social-kultural untuk membangun cita-cita, nilai konsep, prinsip, sikap, dan keterampilan demokrasi dalam diri warga negara melalui pengalaman hidup dan berkehidupan demokrasi dalam berbagai konteks. Mengacu pada visi misi tersebut, Winataputra (dalam Yuniarto, 2018), isi pendidikan demokrasi adalah dapat memfasilitasi warga negara untuk mendapatkan berbagai akses dan menggunakan secara cerdas berbagai sumber informasi sengga memili wawasan yang luas dan memadai, memfasilitasi untuk dapat melakukan kajian konseptual dan operasional, dan memfasilitasi untuk memperoleh dan memanfaatkan kesempatan berpartisipasi. Selain itu, Winataputra (dalam Yuniarto: 2018)

"strategi dasar pendidikan
demokrasi yang seyogyanya
dikembangkan adalah strategi
pemanfaatan aneka media
dan sumber belajar (multy
media and resources), kajian
iterdisipliner (interdisciplinary
studies), pemecahan masalah
social (problem solving),

penelitian social (social inquiry), aksi social( social involment), pembelajaran berbasis portofolio (portofoliobased learning).

Berdasarkan pendapat di atas, maka dapat dipahami bahwa keberhasilan dari pendidikan demokrasi dapat dicapai melalui beberapa strategi, yang salah satu diantaranya adalah melalui proses pembelajaran yang memanfaatkan berbagai media dan sumber belajar. Dalam hal ini salah satu sumber belajar yang dapat digunakan adalah buku ajar, khususnya buku ajar yang kontennya memuat nilainilai demokrasi.

Selanjutnya, Dalton dalam journal of democracy, volume 18 No. 4 juga mengemukakan:

"According to the logic of democratic learning, people should learn democracy's meaning by experiencing a new democratic order, while new incentives and civic-education efforts may also influence their understanding. Put simply, citizens' democratic understanding should be the sum of their individual experiences."

Berdasarkan hal tersebut dapat dipahami bahwa inti dari pendidikan demokrasi yang terwujud dalam tindakan masyarakat adalah adalah kebebasan, diskusi, keterlibatan, dan kesetaraan. Hal mendasar dari keempat poin tersebut adalah bagaimana mahasiswa dapat berkembang menjadi individu yang aktif dan partisipatif berdasarkan pengalaman belajarnya. Berdasarkan hal tersebut dapat dipahami bahwa inti dari masyarakat demokratis adalah kebebasan, diskusi, keterlibatan, dan kesetaraan. Hal mendasar dari keempat poin tersebut adalah bagaimana siswa/ mahasiswa dapat berkembang menjadi 
individu yang aktif dan partisipatif berdasarkan pengalaman belajarnya.

Membahas mengenai pendidikan demokrasi, maka akan ada tantangan tersendiri yang akan dihadapi. Seperti yang dikemukakan oleh Zamroni (2001) bahwa yang menjadi hambatan dalam melaksanakan pendidikan demokrasi, yaitu pendidikannya bersifat indotrinatif yang terkdang membuat peserta didik melakukan hal-hal seremonial dengan terpaksa, materi pelajaran yang terdapat di kelas banyak yang tidak sesuai dengan realita yang ada di masyarakat sehingga kurangnya dukungan dari lingkungan luar sekolah terhadap pembuntakan sikap demokratis tersebut.

Meskipun demikian, suatu proses pembelajaran diharapkan dapat membantu tercapainya tujuan pembelajaran yang telah ditetapkan. Tujuan tersebut dapat berupa ranah kognitif, afektif, dan psikomotorik. Tercapainya tujuan pembelajaran didukung oleh banyak hal salah satunya adalah penggunaan buku ajar. Upaya dalam membentuk masyarakat yang demokratis salah satunya dapat diwujudkan melalui pendidikan di sekolah/perguruan tinggi khususnya juga dalam proses pembelajaran yang berlangsung di kelas. Melalui proses pembelajaran di kelas seorang pendidik dapat memberikan pembelajaran dan pembiasaan untuk membentuk sikap demokratis peserta didiknya. Banyak faktor yang dapat mendukung proses pembelajaran di kelas dalam mewujudkan sikap demokratis mahasiswa salah satunya adalah menyiapkan bahan ajar/ materi yang sesuai. Sebagaimana dikemukakan oleh Suwandi (dalam Suyanto dan Abbas: 2001) bahwa pendidikan dengan tujuan pembentukan sikap dapat dilakukan melalui dua pendekatan, yaitu pendekatan integratife ke mata pelajaran dan penekanan aspek keteladanan. Pendekatan integratif dalam mata pelajaran salah satunya dapat dilakukan dengan mengintegrasikan nilai demokrasi ke dalam materi pembelajaran. Pengintegrasian tersebut dapat dilakukan dengan menggunakan buku ajar yang muatan materinya sudah diinternalisasikan dengan nilai-nilai demokratis. Menurut Akbar (2013) "buku ajar adalah buku teks yang digunakan sebagai rujukan standar pada mata pelajaran tertentu. Ciri-ciri buku ajar adalah: (1) sumber materi ajar; (2) menjadi referensi baku untuk mata pelajaran tertentu; (3) disusun sistematis dan sederhana; dan (4) disertai petunjuk pembelajaran". Selanjutnya, Giyatmi (2016) mengatakan bahwa buku ajar adalah buku pegangan untuk suatu matakuliah yang ditulis dan disusun oleh pakar bidang terkait dan memenuhi kaidah buku teks serta diterbitkan secara resmi dan disebarluaskan. Selanjutnya, Tarigan \& Tarigan (1986) juga mengemukakan bahwa "buku ajar adalah buku yang digunakan sebagai buku pelajaran dalam bidang studi tertentu, yang merupakan buku standar yang disusun oleh pakar dalam bidangnya untuk maksud-maksud dan tujuan instruksional, yang dilengkapi dengan sarana-sarana pengajaran yang serasi dan mudah dipahami oleh para pemakainya disekolah-sekolah dan perguruan tinggi sehingga dapat menunjang suatu program pengajaran". Berdasarkan uraian di atas maka penelitian ini bertujuan untuk mengetahui bagaimana dampak potensial dari penggunaan buku ajar berbasis nilai dalam membentuk sikap demokratis peserta didik.

\section{METODE}

Adapun subjek dalam penelitian ini adalah mahasiswa PPKn angkatan 2018 kelas Palembang yang sedang mengikuti Mata Kuliah Pendidikan Demokrasi. Jenis penelitian yang dipilih adalah deskriptif kuantitatif. Adapun metode pengumpulan data yang digunakan adalah tes dan observasi. Metode pengumpulan diberikan kepada mahasiswa dalam bentuk pretest dan 
postest yang digunakan untuk mengetahui tingkat pemahaman mahasiswa terhadap materi ketika buku ajar pendidikan demokrasi berbasis nilai tersebut digunakan dalam proses pembelajaran. Sebagaimana dikemukakan oleh Sudijono (1996) bahwa pemberian pretest dan posttest adalah untuk mengetahui apakah materi yang disampaikan telah dikuasai dengan baik. Dengan kata lain untuk mengukur kemajuan hasil belajar siswa sebelum dan setelah diberikan materi. Hal ini juga senada dengan pendapat. Asubel (dalam Suciati dan irawan, 2001) bahwa "pretest dan posttest dapat dijadikan pengatur kemajuan belajar". Selanjutnya juga dilakukan pengumpulan data dengan metode observasi. Observasi atau pengamatan merupakan "aktivitas pencatatan fenomena yang dilakukan secara sistematis" (Idrus: 2009). Berdasarkan hal tersebut, observasi dilakukan untuk mengetahui respon dan sikap yang ditunjukkan oleh mahasiswa selama proses pembelajaran berlangsung. Sebagaimana dikemukakan oleh Adler \&Adler (1987) menyebutkan bahwa observasi merupakan salah satu dasar fundamental dari semua metode pengumpulan data dalam penelitian kualitatif, khususnya menyangkut ilmuilmu sosial dan perilaku manusia". Hal tersebut tentu sangat sesuai dengan penelitian ini karena pada prosesnya peneliti mencoba untuk mengamati gejala sosial berupa sikap yang ditunjukkan oleh mahasiswa. Peneliti memilih metode observasi karena mudah dalam melakukan setting serta kegiatannya tersamarkan tanpa disadari oleh objek penelitian sebagiman yang juga dikemukakn oleh (Webb, dkk, 1996). Selanjutnya, Morris (1973) juga menyebutkan bahwa observasi merupakan suatu bentuk aktivitas untuk mencatat dengan bantuan instrument dan merekamnya untuk mencapai suatu tujuan ilmiah. Mengacu pada pendapat tersebut, dalam melakukan observasi peneliti telah menyiapkan instrument yang akan diajukan acuan dalam mengamati sikap demokrasi yang ditunjukkan oleh mahasiswa ketika proses pembelajaran berlangsung. Selanjutnya, akan dilakukan juga analisis data yang didapat dari data observasi selama proses uji coba berlangsung. Analisis dari hasil observasi dilakukan dengan cara deskripsi yang kemudian dipresentasekan, dan diinterpretasikan dengan menggunakan kategori yang dimodifikasi dari Sugiyono (2012) berikut.

Skor

81-100 (Sangat aktif)

61-80 (Aktif)

41-60 (Cukup aktif)

21-40 (Tidak aktif)

$\leq 20$ (Sangat tidak aktif)

\section{HASIL DAN PEMBAHASAN}

Penelitian ini bertujuan untuk mengetahui dampak potensial penggunaan buku ajar Pendidikan Demokrasi berbasis nilai dalam mengembangkan sikap demokratis mahasiswa di Program Studi PPKn FKIP Unsri angkatan 2018 Palembang. Penelitian dilakukan dengan menggunakan metode pengumpulan data berupa tes dan observasi. Pengumpulan data dengan memberikan pre/posttest dimaksudkan untuk mengetahui peningkatan hasil belajar mahasiswa setelah menggunakan buku ajar Pendidikan Demokrasi berbasis nilai. Adapun data hasil pre dan posttest dapat dilihat pada tabel di bawah ini. 


\begin{tabular}{|c|c|c|c|}
\hline No & Mahasiswa & Pretest & Postest \\
\hline 1 & A & 60,3 & 60,3 \\
\hline 2 & B & 33,5 & 60,3 \\
\hline 3 & $\mathrm{C}$ & 40,2 & 33,5 \\
\hline 4 & $\mathrm{D}$ & 53,6 & 73,7 \\
\hline 5 & $\mathrm{E}$ & 40,2 & 60,3 \\
\hline 6 & $\mathrm{~F}$ & 40,2 & 46,9 \\
\hline 7 & G & 40,2 & 87,1 \\
\hline 8 & $\mathrm{H}$ & 46,9 & 87,1 \\
\hline 9 & I & 33,5 & 80,4 \\
\hline 10 & $\mathrm{~J}$ & 60,3 & 100 \\
\hline 11 & $\mathrm{~K}$ & 67 & 80,4 \\
\hline 12 & $\mathrm{~L}$ & 60,3 & 80,4 \\
\hline 13 & M & 60,3 & 73,7 \\
\hline 14 & $\mathrm{~N}$ & 60,3 & 67 \\
\hline 15 & $\mathrm{O}$ & 60,3 & 67 \\
\hline 16 & $\mathrm{P}$ & 60,3 & 80,4 \\
\hline 17 & Q & 60,3 & 73,7 \\
\hline 18 & $\mathrm{R}$ & 53,6 & 87,1 \\
\hline 19 & S & 60,3 & 73,7 \\
\hline 20 & $\mathrm{~T}$ & 67 & 73,7 \\
\hline
\end{tabular}

Berdasarkan data nilai pretest dan posttest di atas maka didapatkan perbandingan nilai rata-rata pretest sebesar 5,3 dan rata-rata nilai posttest sebesar 7,2. Hal tersebut menunjukkan bahwa terdapat selisih nilai sebesar 1,9 dan nilai hasil belajar mahasiswa mengalami peningkatan. Hal tersebut menunjukkan bahwa buku ajar Pendidikan Demokrasi berbasis nilai tersebut membantu dalam meningkatkan hasil belajar mahasiswa dan telah memenuhi kaidah dari buku ajar yang baik. Hal ini sesuai dengan pendapat yang dikemukakan oleh Menurut Akbar (2013) bahwa "buku ajar adalah buku teks yang digunakan sebagai rujukan standar pada mata pelajaran tertentu. Ciri-ciri buku ajar adalah: (1) sumber materi ajar; (2) menjadi referensi baku untuk mata pelajaran tertentu; (3) disusun sistematis dan sederhana; dan (4) disertai petunjuk pembelajaran".

Selanjutnya, selain memberikan angket dan soal pre/posttest, untuk mengetahui dampak potensial (efektifitas) dari buku ajar ini, peneliti juga melakukan observasi terhadap sikap/respon siswa. adapun data hasil observasi dapat dilihat pada tabel berikut.

Tabel 2 Data Hasil Observasi

\begin{tabular}{|c|ccc|}
\hline No & \multicolumn{1}{c|}{ Indikator } & Jumlah & $\mathbf{\%}$ \\
\hline 1. & Mahasiswa antusias memperhatikan penjelasan dosen & 20 & 100 \\
2. & Mahasiswa tidak sibuk dengan aktivitas diluar proses pembelajaran & 20 & 100 \\
3. & Mahasiswa mengajukan pertanyaan kepada dosen & 8 & 40 \\
4. & Mahasiswa menanggapi pertanyaan yang diajukan dosen & 10 & 50 \\
5. & Mahasiswa terlibat aktif selama proses pembelajaran & 10 & 50 \\
6. & Mahasiswa mencoba menunjukkan karakter demokratis selama proses & 20 & 100 \\
& ujicoba berlangsung & & \\
& $\quad$ Total & 98 & 440 \\
\hline
\end{tabular}

\section{Sumber: Data Primer Diolah Tahun 2019}

Berdasarkan penghitungan data observasi di atas, maka didapatkan rata-rata persentase sebesar $73,3 \%$. Nilai rata-rata tersebut menunjukkan bahwa respon siswa selama proses pembelajaran berlangsung adalah baik. Data hasil nilai pre dan post test menunjukkan peningkatan terhadap hasil belajar mahasiswa dari rata-rata 5,3 menjadi 7,2. Selain itu peneliti juga melakukan observasi dengan mempersiapkan lembar observasi untuk mengetahui dampak potensial dari buku ajar tersebut. Berdasarkan hasil data observasi terhadap respon dan sikap siswa selama proses pembelajaran berlangsung didapatkan rata-rata persentase sebesar $73,3 \%$. Hasil persentase tersebut menunjukkan bahwa sikap yang ditunjukkan oleh mahasiswa baik (demokratis). Saat proses pembelajaran berlangsung peneliti melihat bahwa sebagian besar yang mengikuti mata kuliah pendidikan demokrasi dengan menggunakan buku 
ajar berbasis nilai telah menunjukkan partisipasi aktif dalam kegiatan pembelajaran, sikap menghargai terhadap pendapat orang lain, dan mahasiswa juga mengedepankan musyawarah mufakat. Hal ini mencerminkan nilai demokratis yang merupakan salah satu karakter dari delapan belas karakter yang digunakan oleh kemendikbud pada tahun 2010, yaitu demokratis adalah sikap dan cara berpikir yang mencerminkan persamaan hak dan kewajiban secara adil dan merata antara dirinya dengan orang lain. Respon yang ditunjukkan mahasiswa tersebut mengindikasikan bahwa mahasiswa telah menerapkan sikap demokratis dalam lingkup kecil kehidupannya. Hal ini sesuai dengan pendapat Zuriah (2008) juga mengemukakan bahwa dalam memberikan pendidikan demokratis, peserta didik diarahkan untuk dapat menunjukkan sikap saling menghargai berbagai perbedaan yang ada di atara satu sama lainnya. Selian itu hasil penelitian ini juga senada dengan hasil penelitian yang dilakukan oleh Gunarsi dkk (2014) menguraikan bahwa bentuk nilai demokrasi yang ditunjukkan oleh mahasiswa dalam proses pembelajaran dapat berupa malakukan interaksi dengan mahasiswa lain dalam bentuk diskusi, memberikan saran atau pendapat kepada mahasiswa lainnya, berlapang dada dalam menerima saran kritik dari mahasiswa lain, membuat suatu keputusan melalui musyawarah, dan menyelesaikan tugas yang diberikan secara bersama dalam kelompoknya.

Pada tahap observasi, peneliti melihat bahwa setelah diberikan pengetahuan mengenai pelaksanaan nilainilai demokrasi melalui materi ajar yang dikembangkan dengan berbasis nilai, mahasiswa menunjukkan sikap demokrasi yang cukup tinggi terutama dalam hal bermusyarah melalui sebuah diskusi dalam pemecahan masalah yang diberikan. Hal ini tentu merupakan hal positif yang menunjukkan bahwa sikap demokrasi yang ditunjukkan mengacu kepada demokrasi Pancasila. Sebagaiman dikemukakan oleh Sinal (2017) menjelaskan "demokrasi Indonesia adalah kerakyatan yang dipimpin oleh hikmat kebijaksanaan dalam permusyawaratan perwakilan, yang berdasarkan Ketuhanan yang Maha Esa, Kemanusiaan yang Adil dan beradab, persatuan Indonesia, dan bertujuan untuk mewujudkan keadilan sosial bagi seluruh rakyat Indonesia (demokrasi Pancasila)".

Sikap mengedepankan musyawarah mufakat dan saling menghargai terhadap pendapat orang lain tersebut merupakan hal pokok/utama dalam membangun pribadi yang demokratis. Selain itu nilai demokratis juga diitunjukkan dalam bentuk kebebasan, diskusi, keterlibatan, dan kesetaraan. Sebagaimana dikemukakan oleh Dalton dalam journal of democracy, volume 18 No. 4 juga mengemukakan "According to the logic of democratic learning, people should learn democracy's meaning by experiencing a new democratic order, while new incentives and civiceducation efforts may also influence their understanding. Put simply, citizens' democratic understanding should be the sum of their individual experiences."

hal tersebut dapat diamati dalam diri selama proses pembelajaran berlangsung. Kebebasan terlihat dari sikap pendidik dalam memberikan kesempatan kepada para peserta didik untuk mengemukakan pendapat saran yang tentunya dengan cara-cara yang baik atau etis. Hal tersebut juga ditunjukkan oleh mahasiswa dengan memberikan kesempatan kepada peserta didik lainnya untuk menyampaikan pendapatnya. Selain itu penyelesaian permasalahan ditunjukkan oleh para mahasiswa dengan melakukan diskusi 
bukan debat. Dalam proses pembelajaran dengan menggunakan buku ajar pendidikan demokrasi berbasis nilai ini, telah memberikan dampak potensial terhadap sikap demokrasi yang ditunjukkan oleh para mahasiswa. Sebagaimana dikemukakan oleh Suwandi (dalam Suyanto dan Abbas, 2001) bahwa

"pendidikan dengan
tujuan pembentukan sikap
dapat dilakukan melalui
dua pendekatan, yaitu
pendekatan integratife ke
mata pelajaran dan penekanan
aspek keteladanan. Pendekatan
integratife dalam mata pelajaran
salah satunya dapat dilakukan
dengan mengintegrasikan nilai
demokrasi ke dalam materi
pembelajaran."

Pengintegrasian nilai-nilai demokrasi telah peneliti lakukan dalam materi buku ajar pendidikan demokrasi yang digunakan dalam penelitian ini.

\section{SIMPULAN}

Berdasarkan data hasil penelitian yang didapatkan pengerjaan soal pre dan post test, serta hasil observasi selama uji coba berlangsung menunjukkan bahwa buku ajar pendidikan demokrasi berbasis nilai ini efektif dan memiliki dampak potensial yang baik untuk digunakan dalam proses pembelajaran Mata Kuliah Pendidikan Demokrasi sebagai upaya membangun nilai demokrasi pada diri mahasiswa.

\section{DAFTAR PUSTAKA}

Akbar, Sa'dun. 2013. Instrumen Perangkat Pembelajaran. Bandung: PT. Remaja Rosdakarya

Aulawi \& Srinawati. 2019. Implementasi nilainilai demokrasi dalam pengambilan keputusan organisasi untuk meningkatkan organisasi siswa intra sekolah (OSIS) di
SMK Darus Syifa Kota Cilegon. Jurnal Pro Patria. Volume 2. No.1

Azra, A. 2005. Pendidikan Kewarganegaraan untuk Demokratis di Indonesia (https:// media.neliti.com/media/publication/pendidikan-kewarganegaraan-untukdemokrasi-di.pdf. Diakses pada 04 Agustus 2019.

Adler, Patricia A., adler Petter. 1987. Membership Roles in Field Research. Newbury Park, CA: Sage Publication.

Chayati, Nur dkk. 2015. Pengelolaan Pembelajaran Sikap Demokratis di SMP Muhammadiyah 1 Surakarta. Jurnal pendidikan Ilmu Sosial. Vol. 25 No. 2.

Cholisin. 2005. Pengembangan paradigma baru Pendidikan Kewarganegaraan Civic Education) dalam praktek pembelajaran kurikulum berbasis kompetensi. Makalah disajikan dalam Training of Trainers (ToT) Nasional Guru Mata Pelajaran PKn, di Asrama Haji Surabaya. http:// staffnew.uny.ac.id/upload/131 474282/penelitian/PARADIGMA+B ARU+ PKN_0.pdf. Diunduh tanggal 30 Oktober 2017

Dalton, Russel.J. 2007. Understanding democracy: data from Unlikely Places. Journal of Democracy Volume 18, Number 4.

Fadhilah, \& Nuraina. 2011. Penerapan demokrasi di lingkungan gerakan mahasiswa UNISMA Bekasi. Jurnal Kybernan, 2 (2)

Gunarsi dkk. 2014. Pelaksanaan Nilai Demokrasi di Kalangan Mahasiswa. Jurnal Pendidikan Ilmu Sosial. Vol. 24 No. 2.

Kemendiknas. 2010. Buku Induk Pembangunan Karakter. Jakarta.

Kemendiknas. 2003. Undang-Undang Sistem Pendidikan Nasional (SISDIKNAS). Jakarta.

Mufidah, Aktinatun. 2016. Pengembangan Buku Saku Sebagai Bahan Ajar 
Geografi Pada Materi Dinamika Hidrosfer Dan Dampaknya Bagi Kehidupan Di Kelas X IPA SMA Negeri 1 Gedangan. Swara Bhumi, 1 (1) Hal 32-38.

Morris, W. 1973. The American Haritage Dictionary of English Language. Boston: Hougthon Miffin.

Muhibbin, Ahmad \& Sumadjoko, Bambang. 2016. Model Pembelajaran Pendidikan Kewarganegaraan Berbasis Isu-isu Kontroversial Di Media Massa Untuk Meningkatkan Sikap Demokrasi Mahasiswa dan Implikasinya Bagi Masyarakat Madani. Jurnal Pendidikan Ilmu Sosial, 26 (1) Hal 1- 10.

Nurdyansyah \& Lestari, Renti Pujiana. 2018. Pembiasaan Karakter Islam Dalam Pengembangan Buku Ajar Bahasa Jawa Piwulang 5 Pengalamanku Kelas I MI Nurur Rohmah Jasem Sidoarjo. MIDA: Jurnal Pendidikan Dasar Islam, 1 (2) Hal 35-49.

Ranjabar, Jacobus. 2019. Sistem Politik Indonesi. Demokrasi dan pendidikan Politik. Bandung: Alfabeta.

Rodiyana, Roni. 2019. Penerapan Metode Pembelajaran Vct (Value Clarification Technique) Untuk Meningkatkan Sikap Demokratis Siswa Dalam Pembelajaran Pkn Di Sekolah Dasar. Jurnal Cakrawala Pendas, 5 (1) Hal 8-18.

Sinal, M. 2017. Pancasila Konsensus Negara-Bangsa Indonesia. Malang: Madani.

Sugiyono. (2012). Metode Penelitian Kuantitatif, Kualitatif dan $R \& D$. Bandung; CV. Alfabeta;

Suyanto dan Abbas. 2001. Wajah dan Dinamika Pendidikan Anak Bangsa. Yogyakarta: Adicita Karya Nusa.

Suacana. I Wayan Gede. 2015. Nilai-nilai dan parameter demokrasi dalam Kehidupan Masyarakat di Bali.
Jurnal Kajian Bali. Vol. 05 No.01.

Sudijono, Anas. 2001. Pengantar Evaluasi Pendidikan. Jakarta: Raja Grafindo Persada.

Suciati dan Prasetya Irawan. 2001. Teori Belajar dan Motivasi. Jakarta: PAUPPAI. Universitas Terbuka.

Tarigan, Henry. G dan Tarigan, Djoyo. 1986. Telaah buku teks bahasa Indonesia. Bandung: Angkasa

Ulfah, Risti Aulia; Prasetyo, Danang \& Marzuki. 2018. Pengaruh Model Pbm Dalam Pembelajaran Ppkn Terhadap Kemampuan Berpikir Kritis Dan Sikap Demokratis. Citizenship: Jurnal Pancasila dan Kewarganegaraan, 6 (2) Hal 126139.

Winkel, W.S. 2007. Psikologi Pengajaran. Yogyakarta: Media Abadi.

Wahab dan Sapriya. 2011. Teori dan Landasan pendidikan Kewarganegaraan. Bandung: Alfabeta.

Widjaja, A.W. 1986. Manusia Indonesia Individu Keluarga, dan Masyarakat. Jakarta: Akademika Pressindo.

Webb, E., J., dkk. 1996. Unobtrusive Measures Non Reactive Research in the Social Science. Chicago: Rand Mc Nally.

Yuniarto, Bambang. 2018. Pendidikan Demokrasi dan Budaya Demokrasi Konstitusional. Yogyakarta: Deepublish

Zuriah, Nurul. 2008. Pendidikan Moral dan Budi Pekerti dalam Perspektif Perubahan. Jakarta: PT. Bumi Aksara Zamroni. 2001. Pendidikan untuk Demokrasi. Yogyakarta: Bigraf Publising. 